\title{
NUMERICAL ANALYSIS OF PREFABRICATED STEEL-CONCRETE COMPOSITE FLOOR IN TYPICAL LIPSK BUILDING
}

\author{
Piotr LACKI ${ }^{1}$, Przemysław KASZA, Anna DERLATKA \\ Czestochowa University of Technology, Częstochowa, Poland
}

\begin{abstract}
The aim of the work was to perform numerical analysis of a steel-concrete composite floor located in a LIPSK type building. A numerical model of the analytically designed floor was performed. The floor was in a six-storey, retail and service building. The thickness of a prefabricated slab was $100 \mathrm{~mm}$. The two-row, crisscrossed reinforcement of the slab was made from $\varphi 16 \mathrm{~mm}$ rods with a spacing of $150 \times 200 \mathrm{~mm}$. The span of the beams made of steel IPE 160 profiles was $6.00 \mathrm{~m}$ and they were spaced every $1.20 \mathrm{~m}$. The steelconcrete composite was obtained using $80 \times 16$ Nelson fasteners. The numerical analysis was carried out using the ADINA System based on the Finite Element Method. The stresses and strains in the steel and concrete elements, the distribution of the forces in the reinforcement bars and cracking in concrete were evaluated. The FEM model was made from 3D-solid finite elements (IPE profile and concrete slab) and truss elements (reinforcement bars). The adopted steel material model takes into consideration the plastic state, while the adopted concrete material model takes into account material cracks.
\end{abstract}

Keywords: steel-concrete composite floor, FEM

\section{INTRODUCTION}

Steel-concrete composite members consist of elements made from various materials and of various physical properties cooperating with each other due to specially designed connectors. The most popular version of composite beams is constructed of $\mathrm{H}$-section steel beams connected to a concrete floor slab via shear connectors as shown in Fig. 1a [8]. The composite floor slab increases the local

\footnotetext{
${ }^{1}$ Corresponding author: Czestochowa University of Technology, Faculty of Civil Engineering, Dabrowskiego st 69, 42-201 Czestochowa, Poland, e-mail: piotr@lacki.com.pl, tel+48343250965
} 
and lateral stability of the $\mathrm{H}$-section beams and the flexural resistance under sagging moment. As pointed out in $[6,11]$, the connectors greatly influence the strength and ductility of the beam.

The advantages of composite beams have been recognized among others by the authors of $[2,8]$. Steel-concrete composite beams are widely used due to their high loadbearing capacity, full usage of materials, high stiffness and ductility, as well as large energy absorption capacity. Under the same design constraints, composite beams can be more economical than conventional steel beams and lighter than typical reinforced concrete beams. According to [9] the steel-concrete composite girders are used in floors as well as in continuous multi-span bridges. However, H-section composite beams have a large section factor (ratio of fire exposed perimeter to the cross-sectional area of the steel). Therefore, alternative solutions were presented by the authors of [1]. They suggested the use of partially encased PE (Fig. 1b) or slim-floor SF (Fig. 1c) beams which lead to not only reducing storey height but also lowering the section factor in fire.
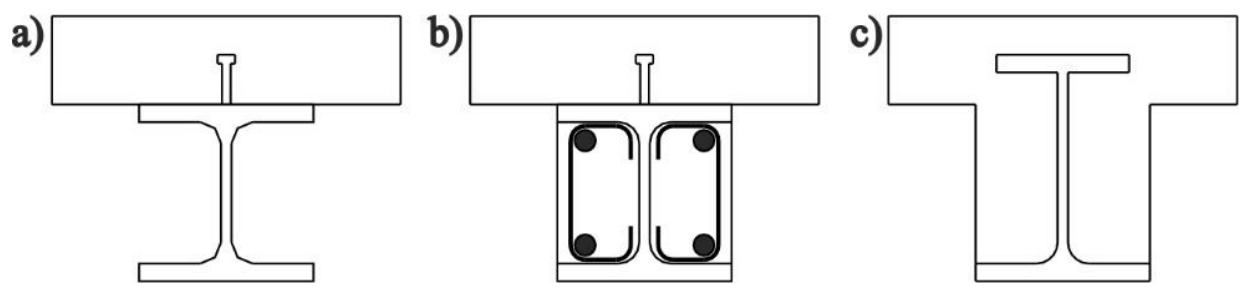

Fig. 1. Cross-section details of composite beams: a) with H-section,

b) partially encased, c) slimfloor

Despite the popularity of composite beams in civil engineering constructions, composite members are still a subject of continuous development. One of the methods of structural analysis is the numerical analysis presented among others in [12]. Paper [3] presents an efficient computer method for nonlinear inelastic analysis of composite steel-concrete beams. The authors of [5] carried out the calculation of buckling (bifurcation) loads of steel-concrete composite beams subjected to negative (hogging) bending. As presented in [7], a three-dimensional finite element model can be developed to investigate the structural behaviour of the composite beam and slab system connected by high-strength friction-grip bolts.

\section{GOAL AND SCOPE OF WORK}

The aim of the work was to perform a numerical analysis of a steel-concrete composite floor located in a Lipsk type building (Fig. 2). 


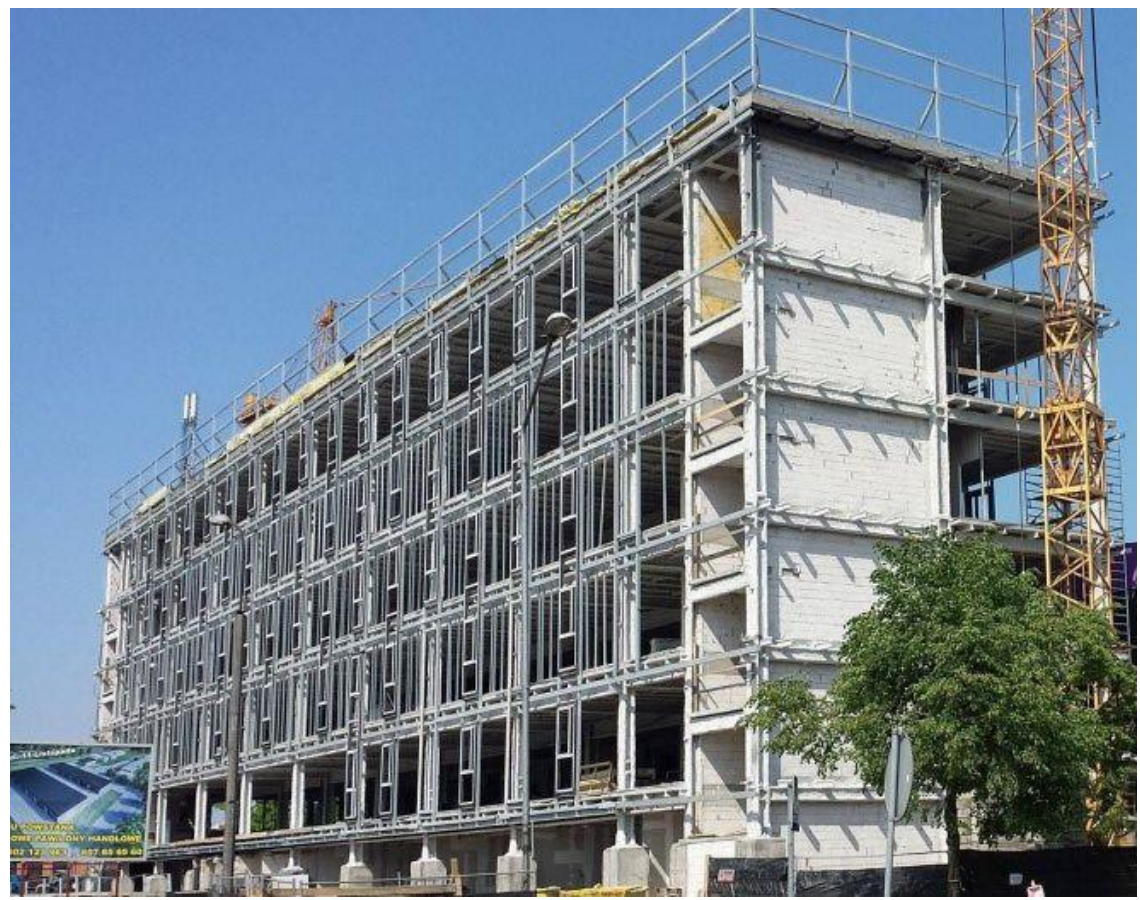

Fig. 2. Reconstruction of typical "Lipsk" building in Czestochowa

The skeleton of the building was designed on a rectangular plan. The prefabricated parts are based on downstand beams located along the building. The floor plan view (Fig. 3) and its cross-sections (Fig. 4 and Fig. 5) are shown below.

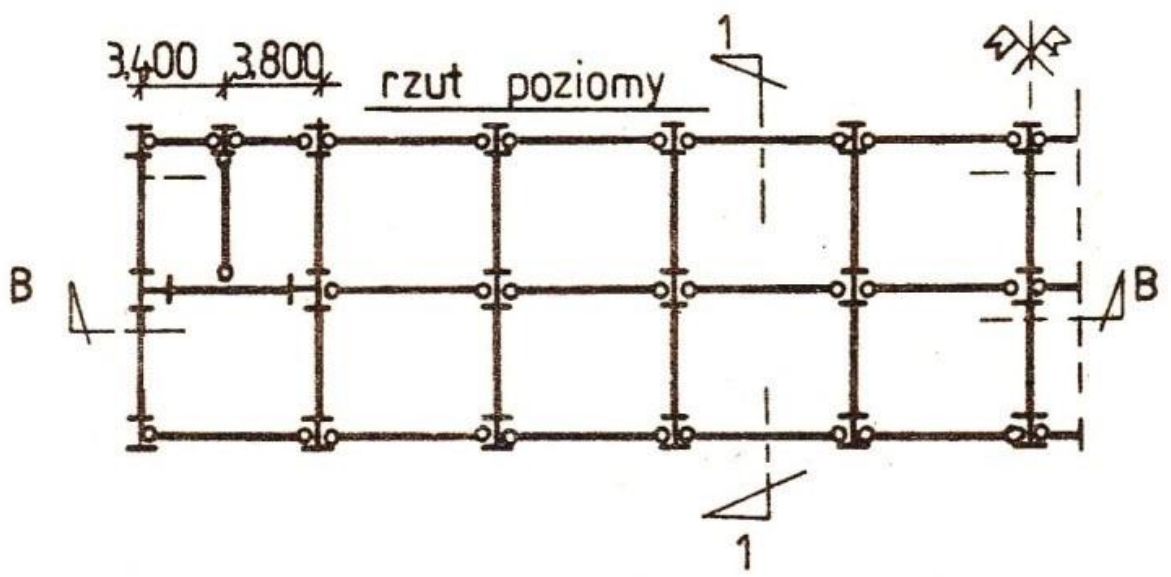

Fig. 3. Floor plan of Lipsk III type building [10] 


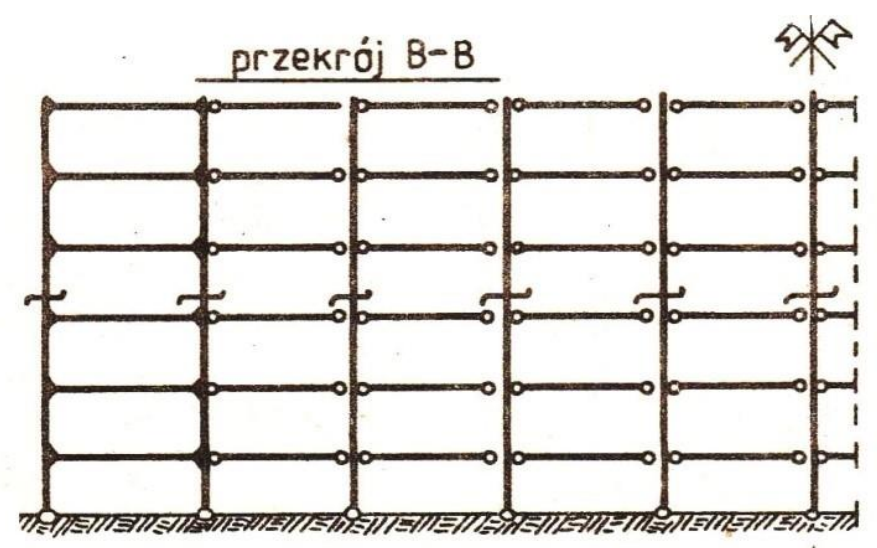

Fig. 4. B-B cross section of Lipsk III type building [10]

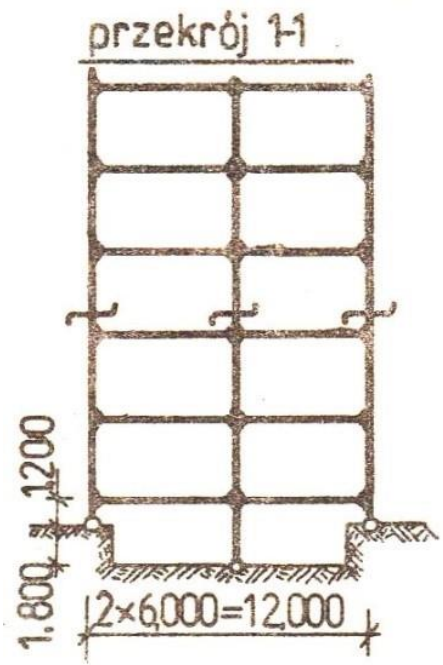

Fig. 5. 1-1 cross section of Lipsk III type building [10]

The building in Czestochowa had an unusual foundation construction for Lipsk buildings. The office building was laid on flat foundations with the stairway at the level of $0.0 \mathrm{~m} \mathrm{AGL}$, not as in the typical case, where the level of \pm 0.0 is on the mezzanine.

A prefabricated single ceiling module consisting of two IPE160 beams and a floor slab with a thickness of $100 \mathrm{~mm}$ was analysed (Fig. 6). The span of the steel beams was $6.00 \mathrm{~m}$, but its spacing was $1.2 \mathrm{~m}$. The joining element was a fastener with a diameter of $16 \mathrm{~mm}$ and a height of $80 \mathrm{~mm}$. Double row, crossed reinforcement of the slab was made from $\varphi 16 \mathrm{~mm}$ rods with a spacing of $150 \mathrm{x}$ $200 \mathrm{~mm}$ (Fig. 7). 


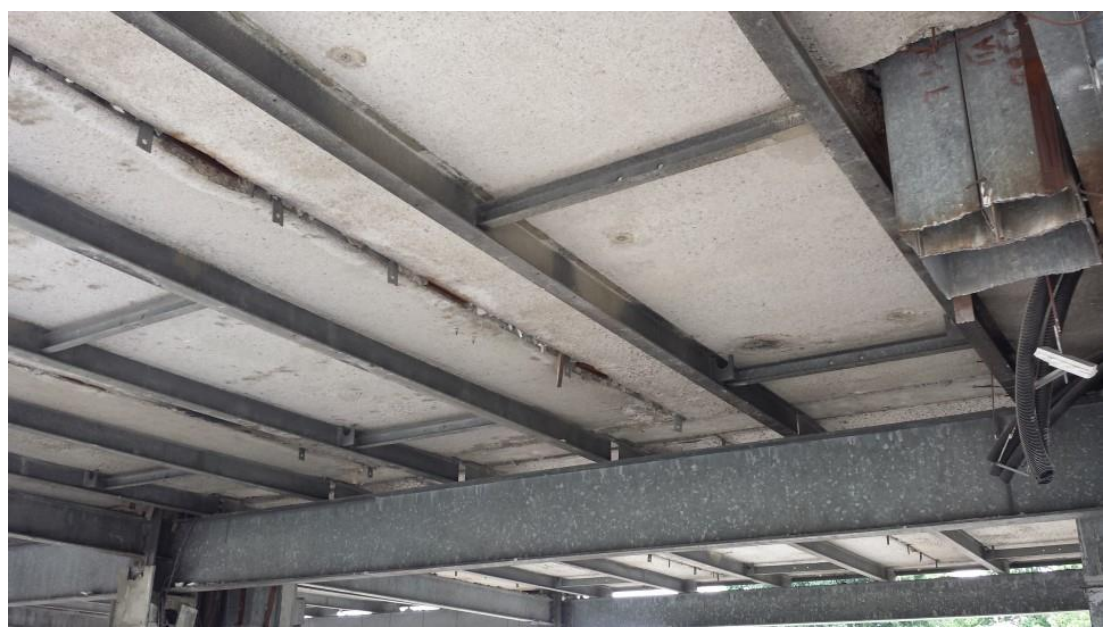

Fig. 6. View of prefabricated building modules of Lipsk type building

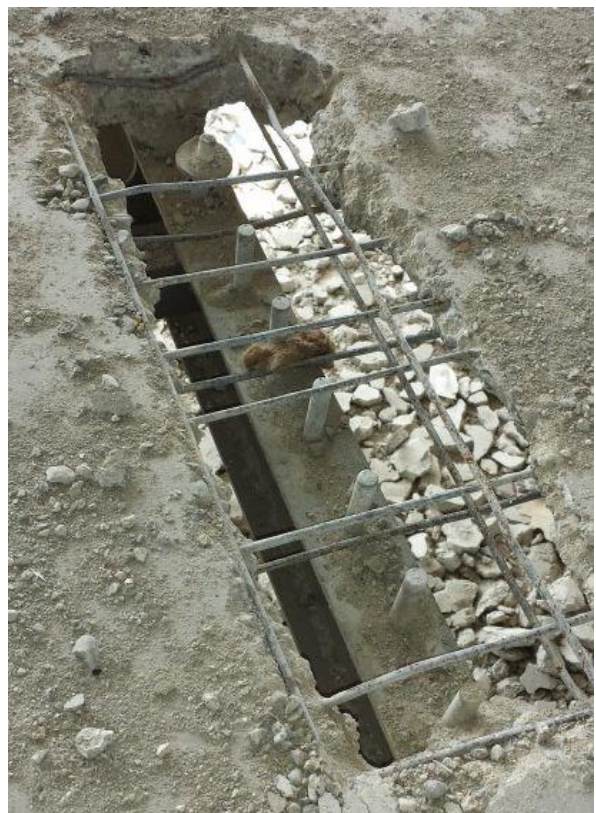

Fig. 7. View of fasteners and reinforcement bars

Based on the analytical calculations according to [4], the following results were obtained:

- vertical displacement in the centre of the beam span $12.49 \mathrm{~mm}$,

- tensile stress in the steel section, in middle of the span 137.4 MPa,

- compressive stresses in the concrete slab, in the middle of the span 6.4 MPa. 


\section{NUMERICAL MODEL}

The second part of the work consists in modelling the composite beam. The beam geometry, load and boundary conditions were used as in the analytical calculations (Fig. 8).

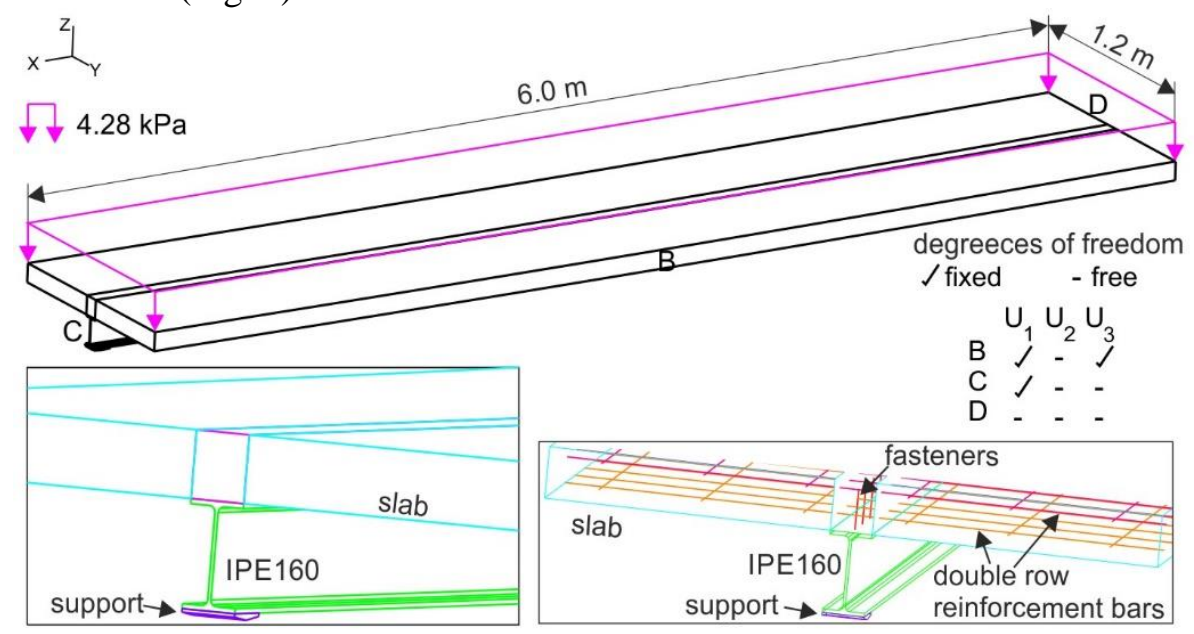

Fig. 8. Composite floor model with marked load and boundary conditions

3D-solid, 27-node finite elements were used for the steel I-profile and concrete. Truss, 3-node finite elements were used for the reinforcement bars and fasteners. The model was loaded with a pressure of $4.28 \mathrm{kPa}$, which corresponds to the characteristic load.

A plastic orthotropic material model with the following parameters:

- Density $\rho=7850 \mathrm{~kg} / \mathrm{m}^{3}$

- Poisson's ratio $v=0,3$

- Modulus of elasticity $\mathrm{E}_{\mathrm{a}}=210 \mathrm{GPa}$

- Yield strength $\mathrm{f}_{\mathrm{y}}=235 \mathrm{MPa}$

- Ultimate tensile strength $\mathrm{f}_{\mathrm{u}}=360 \mathrm{MPa}$

- Elongation $\mathrm{A}_{5}=25 \%$

was used for the I-beam made from S235 structural steel.

A plastic orthotropic material model with the following parameters:

- Density $\rho=7850 \mathrm{~kg} / \mathrm{m} 3$

- Poisson's ratio $v=0,3$

- Modulus of elasticity Es $=205 \mathrm{GPa}$

- $\quad$ Yield strength fsk $=500 \mathrm{MPa}$

- Ultimate tensile strength $\mathrm{fu}=550 \mathrm{MPa}$

- Elongation A5 $=10 \%$

was used for the reinforcement bars made from A-IIIN RB500W steel 
A model with the following parameters (Fig. 9):

- Density $\rho=2500 \mathrm{~kg} / \mathrm{m} 3$

- Tangent modulus at zero strain $\mathrm{E}_{\mathrm{cm}}=30 \mathrm{GPa}$

- Uniaxial cut-off tensile stress $\mathrm{f}_{\mathrm{ctm}}=2,2 \mathrm{MPa}$

- Uniaxial maximum compressive stress (SIGMAC) $\mathrm{f}_{\mathrm{cm}}=28 \mathrm{MPa}$

- Uniaxial compressive strain at SIGMAC $\varepsilon_{\mathrm{cl} 1}=2 \%$

- Uniaxial ulitimate compressive stress $\mathrm{f}_{\mathrm{ck}}=20 \mathrm{MPa}$

- Uniaxial ulitimate compressive strain $\varepsilon_{\mathrm{cu} 2}=3,5 \%$

was used for the $\mathrm{C} 20 / 25$ concrete material.

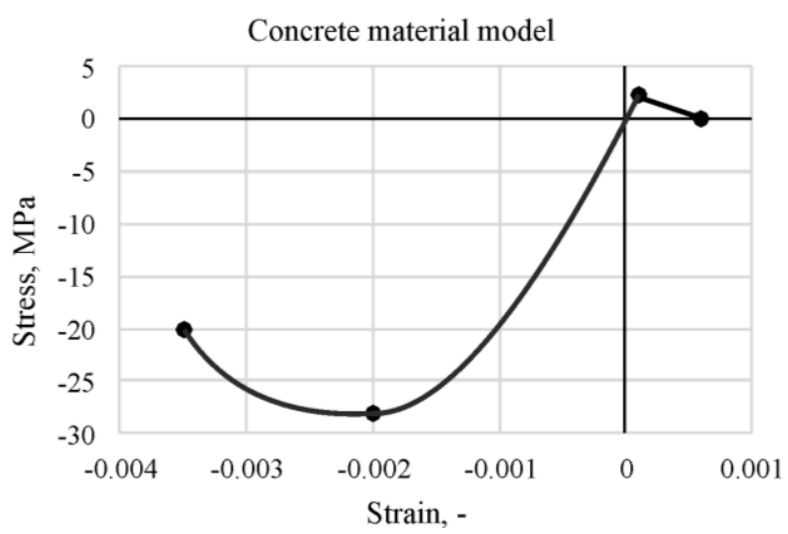

Fig. 9. Concrete material model

\section{RESULTS}

As shown in Fig. 10, the maximum displacement with respect the $\mathrm{Z}$ axis of the concrete slab is $12.56 \mathrm{~mm}$. It is located in the centre of the span, on the edge of the slab. Steel beam displacement of $12.26 \mathrm{~mm}$ occurs in the middle of the span at the top edge of the beam. The analytically calculated displacement equal to $12.49 \mathrm{~mm}$ should be referred to the steel section displacement, which proves an analytical and numerical agreement.

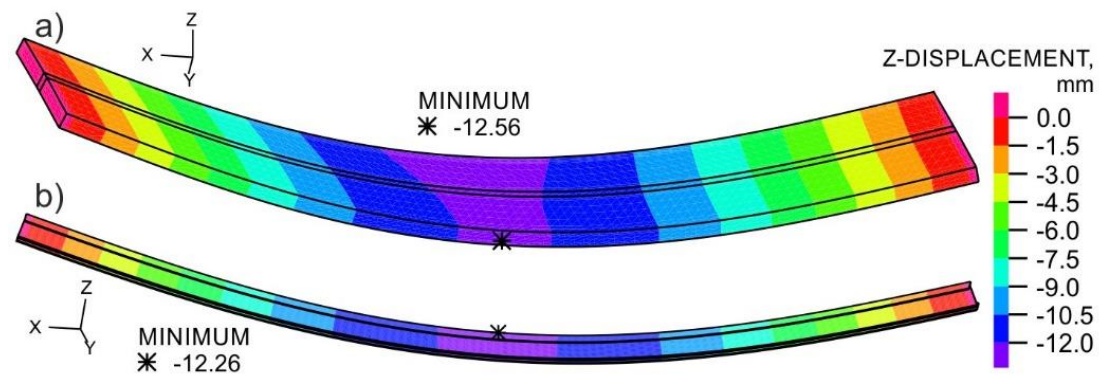

Fig. 10. Z-displacement, mm: a) slab, b) I-beam 
The stress-XX distribution (Fig. 11) shows that the reinforced concrete slab of the existing composite floor is subjected to both compression (minus values) and tensile (plus values). The maximum compression stress is $-5.628 \mathrm{MPa}$ and it is located in the centre of the upper part of the slab. However, the maximum tensile stress $(2.198 \mathrm{MPa})$ is in the middle of the span on the lower edge of the slab. At the same time, the tensile stresses do not exceed the tensile strength of the concrete, which is $2.2 \mathrm{MPa}$.

The compressive stresses in the concrete slab calculated analytically (6.4 MPa) are greater than the stresses determined numerically (5.6 MPa). According to FEM, the stresses are determined by the displacements of the nodes.

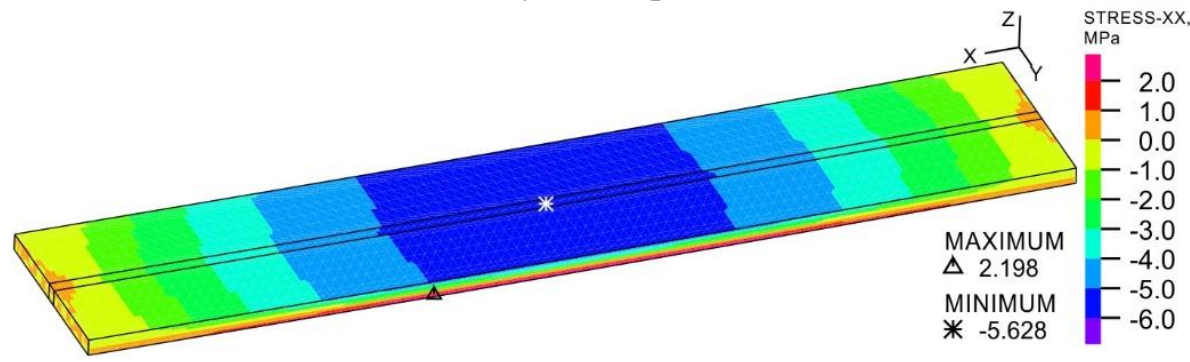

Fig. 11. Normal stresses XX distribution in slab, $\mathrm{MPa}$

The steel I-beam is mainly subjected to stretching. Based on the distribution of normal stresses $X$ in the steel profile (Fig. 12) high compatibility of the stress calculated analytically $137.4 \mathrm{MPa}$ relative to the stress determined numerically 136.9 MPa was observed. The local concentration of compressive stresses occurs in the support zones.

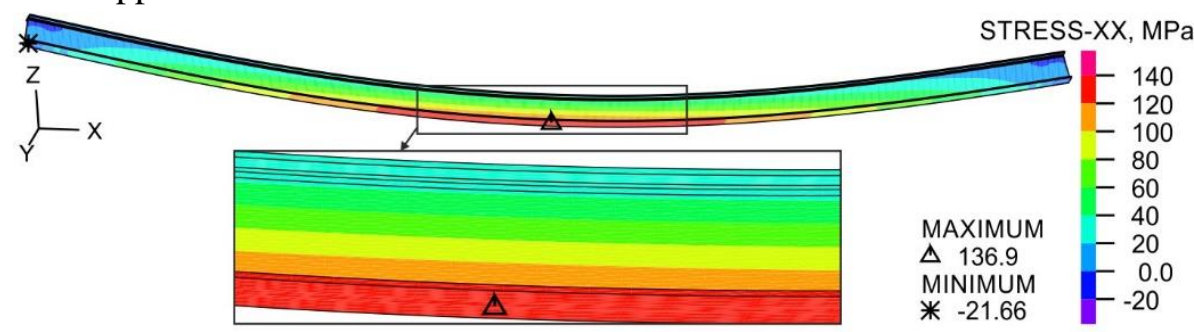

Fig. 12. Distribution of normal stresses $\mathrm{X}$ distribution in I-beam, MPa

When designing of composite floors in accordance with EN 1994-1-1 [4], the stresses in the reinforcing bars are not tested. Despite their small values, such an option exists in numerical calculations.

The distribution of axial stresses in the upper and lower reinforcement bars is presented in Fig. 13. The longitudinal upper reinforcement bars are only compressed (the stress maximum is $-28 \mathrm{MPa}$ ). However, the transverse upper reinforcement bars are only stretched (the stress maximum is $6 \mathrm{MPa}$ ). 
The longitudinal lower reinforcement bars are only stretched. The stresses in these bars vary with the length of the bars. The stress range is from 0 to $9.3 \mathrm{MPa}$. The material effort of the outer bars is greater than the internal bars under which the steel section is located. The transverse upper reinforcement bars are only compressed. The stress range is from 0 to $-7.3 \mathrm{MPa}$.

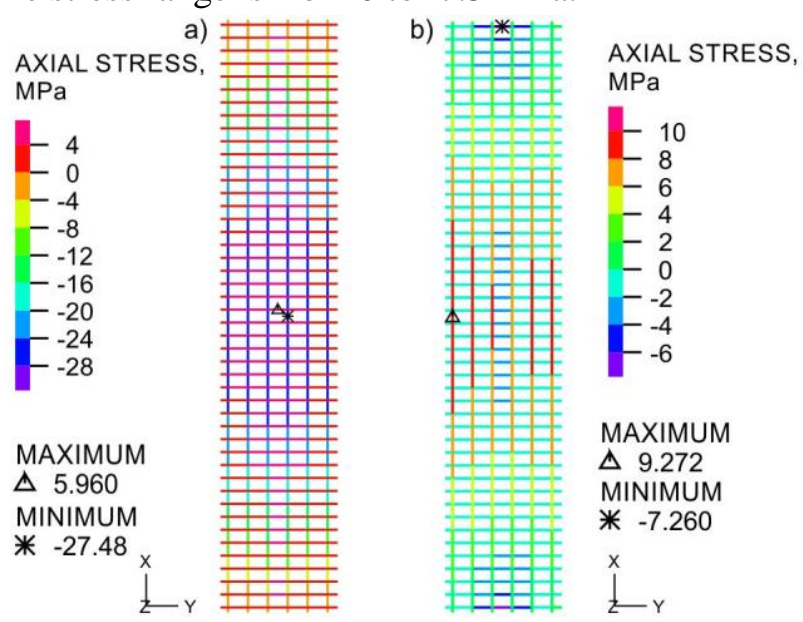

Fig. 13. Distribution of axial stresses in reinforcement bars, MPa: a) upper, b) lower

\section{CONCLUSIONS}

Based on the analysis of the steel-concrete composite floor in the LIPSK building, the following conclusions were made:

- The tensile stresses in the concrete contribute to incomplete use of the material. Performing the optimization of the composite floor for better use of materials is suggested.

- Assuming identical (characteristic) loads, the analytical calculation of floors according to PN-EN 1994-1-1 results in obtaining higher stresses relative to the numerical calculations.

- The floor effort analytically calculated according to PN-EN 1994-1-1 is characterized by a $77 \%$ for the Ultimate Limit States.

- The floor analytically calculated according to PN-EN 1994-1-1 is characterized by the following conditions: $52 \%$ for displacement, $58 \%$ for steel stresses and 23\% for concrete stresses for Serviceability Limit States.

- The numerically calculated floor is characterized by the following conditions: $51 \%$ for displacement, $58 \%$ for steel stresses and $20 \%$ for concrete stresses. 


\section{REFERENCES}

1. Ahn J.-K., Lee C.-H.: Fire behavior and resistance of partially encased and slim-floor composite beams, Journal of Constructional Steel Research, 129 (2017) 276-285.

2. Budziak M., Grabowski T.: Failure Assessment of Steel-Concrete Composite Column Under Blast Loading, Engineering Transactions, 62, 1 (2014) 61-84.

3. Chiorean C. G., Buru S. M.: Practical nonlinear inelastic analysis method of composite steel-concrete beams with partial composite action, Engineering Structures, 134 (2017) 74-106.

4. Eurokod 4: Projektowanie zespolonych konstrukcji stalowo-betonowych. Część 1-1: Reguly ogólne i reguly dla budynków., PN-EN 1994-1-1.

5. Henriques D., Gonçalves R., Camotim D.: GBT-based finite element to assess the buckling behaviour of steel-concrete composite beams, Thin-Walled Structures, 107 (2016) 207-220.

6. Kucharczuk W., Labocha S.:, Efektywność rozwiazań konstrukcyjnych stropu $w$ zależności od stopnia zespolenia ptyty betonowej z belka stalowa, Konstrukcje stalowe, 5, 124 (2013) 30-31.

7. Liu X., Bradford M. A., Ataei A.: Flexural performance of innovative sustainable composite steel-concrete beams, Engineering Structures, 130 (2017) 282-296.

8. Liu Y., Guo L., Qu B., Zhang S.: Experimental investigation on the flexural behavior of steel-concrete composite beams with $U$-shaped steel girders and angle connectors, Engineering Structures, 131 (2017) 492-502.

9. Machelski C., Toczkiewicz R.: Effects of connection flexibility in steelconcrete composite beams due to live loads, Archives of Civil and Mechanical Engineering, 6, 1 (2006) 65-86.

10. Machowski A., Murzewski J.: Szkielety stalowe budynków wielokondygnacyjnych, Kraków, Wydaw. Politechniki Krakowskiej im. Tadeusza Kościuszki 1988.

11. Mashiri F. R., Mirza O., Canuto C., Lam D.: Post-fire Behaviour of Innovative Shear Connection for Steel-Concrete Composite Structures, Structures, 9 (2017) 147-156.

12. Wróblewski T., Berczyński S., Abramowicz M.:, Estimation of the parameters of the discrete model of a steel-concrete composite beam, Archives of Civil and Mechanical Engineering, 13, 2 (2013) 209-219. 


\section{ANALIZA NUMERYCZNA MODELU PREFABRYKOWANEGO STROPU ZESPOLONEGO TYPOWEGO BUDYNKU LIPSK}

\section{Streszczenie}

Celem pracy była analiza numeryczna zespolonego stropu znajdującego się w budynku typu LIPSK. Wykonano numeryczny model stropu zaprojektowanego analitycznie. Strop znajdował się w sześciokondygnacyjnym budynku handlowo-usługowym. Grubość płyty prefabrykowanej wynosiła $100 \mathrm{~mm}$. Dwurzędowe, krzyżowe zbrojenie płyty wykonano z prętów $\varphi 16 \mathrm{~mm}$, w rozstawie 150 x $200 \mathrm{~mm}$. Rozpiętość belek wykonanych ze stalowego profilu IPE 160 wynosiła $6,00 \mathrm{~m}$. Belki rozstawiono co 1,20 m. Zespolenie stalowo-betonowe uzyskano za pomocą łączników firmy Nelson 80x16. Analizę numeryczną przeprowadzono za pomocą programu ADINA System opartego na Metodzie Elementów Skończonych. Dokonano oceny naprężeń i odkształceń w elemencie stalowym i betonowym, rozkładu sił w prętach zbrojenia oraz zarysowania betonu. Model MES zbudowano w oparciu o elementy 3D Solid (profil IPE i płyta żelbetowa) oraz prętowe typu truss (zbrojenie). Dla stali przyjęto właściwości i model materiału uwzględniający stan plastyczny, dla betonu przyjęto model materiału uwzględniający powstawanie rys.

Słowa kluczowe: $\quad$ strop zespolony, MES

Editor received the manuscript: 05.09.2017 